\title{
Pengalaman ODHA Menjalani Voluntary Counseling and Testing (VCT)
}

\author{
Sinthia Rosanti Maelissa \\ Program Studi Keperawatan Universitas Kristen Indonesia Maluku \\ Email : maelissasinthia@gmail.com
}

\begin{abstract}
Abstrak
Pendahuluan: Orang dengan HIV AIDS (ODHA) akan mengalami krisis afektif pada diri sendiri, keluarga, dan masyarakat, dalam bentuk kepanikan, ketakutan, kecemasan, serba ketidakpastian, keputusasaan, dan stigma yang berdampak pada kualitas hidup, sehingga membutuhkan penanganan setiap problem yang dialami ODHA, salah satunya adalah program Voluntary Counseling and Testing (VCT).
\end{abstract}

Tujuan: penelitian ini bertujuan untuk menguraikan secara mendalam tentang pengalaman ODHA menjalani VCT.

Metode: Desain penelitian ini adalah fenomenologi deskriptif dengan pendekatan kualitatif. Penelitian ini berlangsung selama 1 bulan dengan jumlah partisipan 10 orang yang dipilih dengan menggunakan teknik purposive sampling. Partisipan dipilih dengan bantuan petugas puskesmas sebagai gatekeeper yang telah diberikan penjelasan sebelumnya terkait tujuan penelitian dan kriteria partisipan. Teknik analisis data menggunakan pendekatan analisis selektif dan focusing.

Hasil: penelitian ini mengidentifikasi tiga tema utama yaitu : 1) pentingnya mengikuti VCT, 2) proses mnjalani VCT, dan 3) hasil dari proses yang dijalani.

Kesimpulan: ODHA merasakan pentingnya mengikuti VCT untuk dapat mendeteksi penyakit secara dini dan memperoleh pengobatan serta dukungan sosial untuk menghadapi stigma dan diskriminasi.

Kata kunci: Orang dengan HIV AIDS , Voluntary Counseling and Testing (VCT), Kualitas Hidup

\section{Pendahuluan}

Arus Globalisasi telah membawa pergeseran nilai pada masyarakat Indonesia dari nilai-nilai yang bersifat tradisional menjadi modern dan secara langsung mengubah gaya hidup menjadi hedonis, hura-hura, lokalisasi, konsumsi narkoba dan perilaku sex bebas yang akhirnya membawa risiko terhadap penyakit menular, salah satunya yaitu

\begin{abstract}
Introduction: People with HIV AIDS will experience an effective crisis in themselves,family and public such as panic, fear, anxiety, uncertainty, hopelessness, and stigma that have an impact for life quality. so it requires handling every problem that experienced,one of them is Voluntary Counseling and Testing (VCT) program..
\end{abstract}

Objective: the purpose of this research is to describe the experience of them after becoming VCT deeply.

Method: the design of this research is descriptive phenomenology with a qualitative approach. this research needs a month with 10 participants which selected used purposive sampling technicque. The participants which selected with help of the health center staff as gatekeeper who had been given explanation before related the purpose of the reserach and participants criteria. The data analysis techniques the selective or highlighting approach.

Result: this research identifies three themes: 1) How importent to follow VCT, 2) the process of $V C T, 3)$ The result of the process.

Conclusion: They think how important to follow VCT to detect the desease early and obtain treatment and support to deal with stigma and discrimination.

Keywords: People with HIV AIDS, Voluntary Counseling and Testing(VCT), Life quality.

Acquired Immune Deficienty Syndrome (AIDS) yang diakibatkan oleh Human Immunodeficiency Virus (HIV). ${ }^{1}$ Indonesia menjadi salah satu negara yang termasuk dalam kawasan Asia Pasifik. Kawasan ini menduduki peringkat ketiga sebagai wilayah dengan pengidap HIV/AIDS 
terbanyak di seluruh dunia dengan total penderita sebanyak 5,2 juta jiwa. Dalam laporan perkembangan HIV-AIDS pada bulan april sampai dengan juni 2018, jumlah orang yang terinfeksi HIV di Indonesia sebanyak 10.830 dengan persentase tertinggi pada kelompok umur 25-49 tahun (70,3\%) diikuti kelompok 20 sampai 24 tahun $(15,9 \%)$ dan kelompok umur $\geq$ 50 tahun $(7,6 \%)$ sedangkan di Malukusebanyak 462 orang yang diakibatkan karena hubungan seks berisiko pada Heteroseksual, Lelaki seks lelaki (LSL) dan penggunaan alat suntik tidak steril pada penasun. Persentase tersebut mengalami peningkatan dibanding bulan Januari sampai Maret hanya 10.506 orang. Sedangkan jumlah AIDS di Indonesia sampai juni 2018, dilaporkan sebanyak 1.864 dan 68 diantaranya ada di Maluku. ${ }^{2}$

Orang dengan HIV/AIDS (ODHA) memerlukan terapi antiretroviral therapy (ARV) untuk dapat memperlambat penyebaran virusnya agar bisa hidup lebih lama. Namun ODHA tidak hanya memerlukan penanganan klinis semata tetapi juga pendekatan dari segi bio psiko sosio dan spiritual. ODHA akan mengalami krisis afektif pada dirinya, keluarganya, orang-orang yang dicintainya dan masyarakat, dalam bentuk kepanikan, ketakutan, kecemasan, serba ketidakpastian, keputusasaan, dan stigma yang berdampak pada kualitas hidup penderita. Kualitas hidup merupakan komponen penting dalam evaluasi kesejahteraan dan kehidupan ODHA. ${ }^{3}$

Peraturan Menteri Kesehatan Republik Indonesia No.21 tahun 2013 tentang penanggulangan HIV dan AIDS, menjelaskan bahwa untuk pemeriksaan diagnosis HIV dapat dilakukan dengan konseling dan Tes HIV sukarela atau Voluntary Counseling and Testing (VCT) yang meliputi konseling pra tes, tes HIV dan konseling pasca tes secara sukarela dan rahasia agar mendapatkan perawatan dan dukungan terhadap kompleksnya problem yang dihadapi sekaligus sebagai strategi efektif pencegahan HIV. ${ }^{4}$ Berdasarkan data profil Kesehatan Indonesia, jumlah Pelayanan VCT terus mengalami peningkatan, pada tahun 2018 tercatat sebanyak 6.657 layanan di Indonesia pada umumnya sedangkan di Maluku terdapat 88 layanan klinik VCT. Jumlah klien yang berkunjung dan yang mengikuti konseling setelah tes HIV sebanyak 25.477 sedagkan jumlah klien yang menjalani tes HIV dan yang mengikuti konseling setelah tes HIV sebanyak 25.466 orang. Kota Ambon memiliki persentase layanan dan kunjungan terbesar (65\%) dibandingkan kota dan kabupaten lainnya di Maluku. ${ }^{5}$

Proses konseling dan tes yang diikuti ODHA akan memberikan gambaran dan karakteristik yang berbeda-beda antara satu dengan yang lainnya terhadap kualitas hidup yang dirasakan setelah menjalani VCT. Respon tersebut dapat dipengaruhi oleh beberapa hal diantaranya pendidikan, jenis kelamin, dan usia, sehingga juga mempengaruhi arti dan makna seseorang terhadap fenomena, untuk dapat dieksplorasi secara mendalam melalui sebuah penelitian kualitatif dengan pendekatan fenomenologi. Tujuan dari penelitian ini adalah untuk menguraikan secara mendalam tentang pengalaman ODHA menjalani VCT.

\section{Metode}

Metode penelitian yang digunakan dalam penelitian ini adalah metode penelitian kualitatif dengan pendekatan fenomenologi deskriptif. Pendekatan fenomenologi adalah strategi yang digunakan peneliti untuk mencari atau menemukan makna dari hal-hal yang esensial atau mendasar dari pengalaman hidup pada individu dengan fenomena-fenomena yang dihadapi dalam suatu situasi tertentu ${ }^{(6)}$. Pada penelitian ini pendekatan fenomenologi digunakan untuk mendapatkan pemahaman lebih dalam mengenai kualitas hidup ODHA yang menjalani VCT. Pendekatan yang digunakan dalam penelitian ini adalah fenomenologi deskriptif yang terdiri dari empat tahap yaitu bracketing, intuiting, analyzing, dan describing ${ }^{7}$.

Populasi dalam penelitian kualitatif adalah fenomena atau situasi sosial itu sendiri. ${ }^{8}$ Populasi dalam penelitian ini adalah ODHA yang tinggal Kecamatan Nusaniwe Kota Ambon. Pada penelitian kualitatif, istilah partisipan atau informan digunakan pada yang memberikan informasi. Partisipan atau informan 
inilah yang secara aktif ikut berpartisipasi mengeksplor pengalaman hidupnya kepada peneliti dalam penelitian. Jumlah partisipan disesuaikan dengan kelengkapan informasi yang diperlukan peneliti sehingga tercapai kejenuhan (saturasi data), artinya bahwa tidak ada informasi baru dan terjadi pengulangan informasi dari partisipan sebelumnya. ${ }^{9}$ Jumlah partisipan dalam penelitian ini yaitu sebanyak 10 orang dengan kategori usia 25-40 tahun, yang dipilih dengan menggunakan teknik purposif sampling.

Penelitian ini dilaksanakan di Wilayah Kerja Puskesmas Waihaong, Kecamatan Nusaniwe, Kota Ambon selama 1 bulan yang dilalui dengan proses etik pada Lembaga Penelitian Universitas Kristen Indonesia Maluku.

Prosedur Pengumpulan data dimulai dari Peneliti dan gatekeeper mendatangi calon partisipan untuk melakukan pendekatan kemudian melakukan kontrak waktu dan tempat melakukan wawancara. Peneliti memberikan lembar informed consent, mempersiapkan voice recorder untuk merekam pembicaraan selama wawancara dilakukan. Hasil wawancara kemudian disalin menjadi verbatim, kemudian menggolongkan data kedalam kategori atau tema, dan mensintesis data kedalam tabel.

Hasil dan Pembahasan

Tabel.1. Karakteristik Partisipan

\begin{tabular}{|c|c|c|c|}
\hline No & $\begin{array}{c}\text { Karak- } \\
\text { teristik } \\
\text { Partisipa } \\
\text { n } \\
\end{array}$ & $\begin{array}{c}\text { Sub Karak- } \\
\text { teristik } \\
\text { partisipan }\end{array}$ & $\begin{array}{c}\text { Kode } \\
\text { Partisipan }\end{array}$ \\
\hline 1 & Umur & $\begin{array}{l}27,28,29,31, \\
32,38,39,40\end{array}$ & $\begin{array}{l}\text { P1, P2, P3, } \\
\text { P4, P5, P6, } \\
\text { P7, P8, P9, } \\
\text { P10 }\end{array}$ \\
\hline 2 & $\begin{array}{l}\text { Jenis Ke- } \\
\text { lamin }\end{array}$ & $\begin{array}{l}\text { Laki-Laki dan } \\
\text { Perempuan }\end{array}$ & $\begin{array}{l}\text { P1, P2, P3, } \\
\text { P4, P5, P6, } \\
\text { P7, P8, P9, } \\
\text { P10 }\end{array}$ \\
\hline 3 & $\begin{array}{l}\text { Pendidi- } \\
\text { kan }\end{array}$ & SMA & $\begin{array}{c}\text { P1, P2, P3, } \\
\text { P4, P5, P6, } \\
\text { P7, P8, P9, } \\
\text { P10 }\end{array}$ \\
\hline
\end{tabular}

Tema pertama : Pentingnya melakukan Voluntary Counselling Test (VCT).

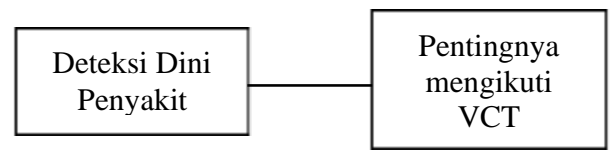

Hasil penelitian menunjukan bahwa ODHA menganggap Voluntary Counseling Test (VCT) merupakan sebuah program yang sangat bermanfaat karena dapat memberikan informasi tentang penyakit yang diderita lebih dini.

VCT adalah proses konseling pra testing, konseling post testing, dan testing HIV secara sukarela yang bersifat confidential dan secara lebih dini membantu orang mengetahui status HIV. Konseling pra testing memberikan pengetahuan tentang HIV \& manfaat testing, pengambilan keputusan untuk testing, dan perencanaan atas issue HIV yang akan dihadapi. Konseling post testing membantu seseorang untuk mengerti \& menerima status (HIV+) dan merujuk pada layanan dukungan. Konseling dalam VCT adalah kegiatan konseling yang menyediakan dukungan psikologis, informasi dan pengetahuan HIV/AIDS, mencegah penularan HIV, mempromosikan perubahan perilaku yang bertanggungjawab, pengobatan ARV dan memastikan pemecahan berbagai masalah terkait dengan HIV/AIDS.

Konseling dan Tes HIV sukarela di klinik VCT adalah titik awal pelayanan dan perawatan yang berkelanjutan dan merupakan tempat mereka datang untuk bertanya, belajar dan menerima status HIV seseorang dengan privasi yang terjaga, yang mampu menjangkau dan menerapkan perawatan dan upaya pencegahan yang efektif oleh seorang counselor yang terlatih.

Penelitian yang dilakukan Yeni (2016) menunjukan bahwa VCT dapat mengubah persepsi masyarakat tentang proses penyakit, serta stigma dan diskriminasi terhadap ODHA. ${ }^{10} \mathrm{Hal}$ ini juga sejalan dengan penelitian yang dilakukan oleh Nurul (2015) bahwa praktik konseling bertujuan untuk meningkatkan pengetahuan serta membangkitkan kesadaran klien 
dan mendorong untuk merubah perilaku beresikonya. ${ }^{11}$

\section{Tema kedua : Proses menjalani VCT.}

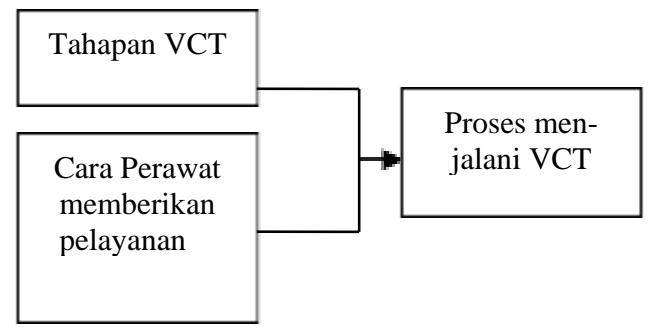

Hasil penelitian menunjukan bahwa ODHA yang akan mengikuti VCT terlebih dahulu mengikuti konseling pra test dengan perawat yang berperan sebagai konselor. Dalam konseling pra test ODHA diminta untuk jujur terkait setiap perilaku berisiko yang dilakukan selama ini baik riwayat aktifitas seksual, penggunaan Narkoba suntik, atau pernah menerima transfusi darah, memiliki pengalaman tato ataupun penyakir terdahulu. Tahap kedua adalah ODHA diminta persetujuannya untuk melakukan test, bila hasil tes positif maka selanjutnya ada tahapan pasca Tes yaitu konselor akan memberikan dukungan emosional agar penderita tidak patah semangat, kemudian konselor memberikan informasi selanjutnya untuk pengobatan yang perlu dijalani termasuk memberikan edukasi untuk bagaimana agar tidak menularkan ke orang lain.

ODHA juga menggambarkan tentang pelayanan yang diberikan para perawat yang bertugas di ruang VCT membuat ODHA merasa nyaman sehingga tidak hanya secara fisik ODHA bisa diobati namun juga secara psikis ODHA merasakan adanya dukungan yang baik

Proses VCT dilakukan dalam beberapa tahap yaitu; tahap pre test yang meliputi : 1) mengemukakan alasan test, 2) pengetahuan tentang HIV \& manfaat testing, 3) perbaikan kesalahpahaman ttg HIV / AIDS, 4) penilaian pribadi resiko penularan HIV, 5) Informasi tentang test HIV, 6) diskusi tentang kemungkinan hasil yang keluar, 7) kapasitas menghadapi hasil / dampak hasil,(8) kebutuhan dan dukungan potensial - rencana pengurangan resiko pribadi, 9) pemahaman tentang pentingnya test ulang, 10) memberi waktu untuk mempertimbangkan, 11) pengambilan keputusan setelah diberi informasi, 12) membuat rencana tindak lanjut, 13) memfasilitasi dan penandatanganan Informed Consent. Selanjutnya adalah tahap pasca test yang meliputi : 1) dokter \& konselor mengetahui hasil untuk membantu diagnosa dan dukungan lebih lanjut, 2) hasil diberikan dalam amplop tertutup, 3) hasil disampaikan dengan jelas dan sederhana, 4) beri waktu untuk bereaksi, 5) cek pemahaman hasil test, 6) diskusi makna hasil test

Setiap tahapan pelayanan VCT akan membantu ODHA untuk memperoleh hasil yang lebih baik, sehingga memerlukan kepatuhan ODHA pada setiap tahapannya. Keptuhan ODHA dipengaruhi oleh beberapa faktor yaitu lingkungan, model terapi dan interaksi profesional antara konselor dan pasien. ${ }^{12}$ Kepatuhan juga dapat dipengaruhi oleh motivasi untuk sembuh dari ODHA, dukungan sosial dan hubungan yang terjalin baik dengan tenaga kesehatan. ${ }^{13}$

\section{Tema ketiga:hasil dari proses yang dijalani.}

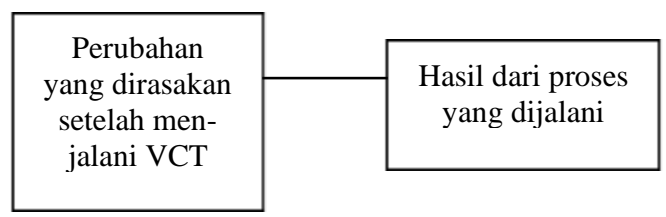

Hasil penelitian menunjukan bahwa ODHA merasakan adanya perubahan secara fisik setelah menjalani pengobatan ARV dan juga perubahan secara psikologi, sosial dan spiritual karena adanya berbagai tahapan yang mereka lalui. Hal ini menggambarkan adanya peningkatan kualitas hidup ODHA dibanding sebelum mengikuti VCT.

Hasil dari proses pengobatan, merupakan suatu proses yang dimana seseorang mengalami perubahan fisik dan psikologi. Secara fisik, ODHA akan mengalami lebih kuat setelah mendapatkan terapi ARV karena secara langsung akan mengurangi terjadinya infeksi opotunistik, menghentikan replica virus HV dan memulihkan system imun. ${ }^{3,13}$. Kesehatan fisik 
ini berhubungan dengan perubahan yang dialami ODHA yaitu seperti penurunan berat badan yang terjadi secara drastis dan munculnya penyakit penyerta. Adanya penyakit penyerta pada ODHA dapat menyebabkan penurunan kemampuan ODHA dalam melakukan aktivitas sehati-hari dan intensitas istirahat serta mengakses layanan kesehatan akan lebih banyak. ${ }^{13}$

Kualitas hidup merupakan komponen penting dalam evaluasi kesejahteraan dan kehidupan ODHA. Kualitas hidup memiliki enam pokok diantaranya kesehatan fisik, kesehatan psikologis, tingkat kemandirian, hubungan sosial, lingkungan serta keadaan spiritual. ${ }^{15}$

Salah satu faktor yang mempengaruhi kualitas hidup ODHA adalah lama menjalani terapi. Semakin lama seseorang menjalani VCT maka semakin tinggi kualitas hidupnya. ${ }^{16,17} \mathrm{Hal}$ ini diakibatkan karena semakin banyak konseling dan pengobatan yang dilakukan oleh ODHA. ${ }^{15}$ ODHA yang mengikuti VCT, menjalani hidupnya secara positif, adanya stigma negatif dan diskriminasi yang diterima di masyarakat bukan suatu hal untuk menarik diri, bahkan tetap aktif dan produktif dalam menjalani aktivitas sehari-hari. ${ }^{3,14}$

\section{Kesimpulan}

Berdasarkan hasil penelitian yang diperoleh, maka dapat disimpulkan bahwa setelah menjalani Voluntary Counseling and Testing VCT: ODHA merasakan pentingnya mengikuti VCT karena dapat memberikan informasi tentang penyakit yang diderita lebih dini; ODHA mengikuti setiap tahap dalam VCT mulai dari konseling pre test, melakukan test, sampai pada tahap pasca test; ODHA merasakan adanya perubahan baik secara fisik, psikis, social dan spiritual dalam setiap tahapan yang dilalui.

\section{Ucapan Terima Kasih}

Terimakasih disampaikan kepada Lembaga Penelitian Universitas Kristen Indonesia Maluku yang telah memberikan dana kepada penulis untuk melakukan penelitian.

\section{Daftar Pustaka}

1. UNAIDS. Global AIDS Update 2016. http://www.unaids.org/sites/default/files/media_asset/global-AIDS-update-2016_en.pdf

2. Kementrian, Kesehatan RI. Laporan Situasi Perkembangan HIV \& AIDS di Indonesia April - Juni 2018. Ditjen P2P

3. Nursalam, Ninuk Dian K, Misutarno, Fitiana Kurniasari. S. Asuhan keperawatan pada pasien terinfeksi HIV AIDS: Jakarta: Salemba Medika; 2018.

4. Kemenkes. 2013. PERMENKES RI No 21 tahun 2013 tentang penanggulangan HIV/AIDS. http://pppl.depkes.go.id/_asset/_regulasi/100_Pe rmenkes\%20No\%2021\%20Tahun\%202013\%20 Penanggulangan\%20HIVAIDS.pdf

5. Kementrian Kesehatan RI, Data dan Informasi, Profil Kesehatan Indonesia 2017; 2018.

6. Creswell, J. W. Research design: Qualitative, quantitative, and mixed methods approaches $\left(4^{\text {th }}\right.$ ed). California: SAGE Publication; 2015.

7. Polit. D. F. \& Beck. C. T. Nursing Research: Prinsiple and Methodes. ( $7^{\text {the }}$ ). Philadhelphia: Lippincot William \& Wikins; 2012.

8. Streubert, H.J. \& Carpenter, D.R Qualitaive research in nursing: advancing the humanistic imperative $\left(5^{\text {th }}\right.$ ed). Lippincott: Williams \& Wilkins; 2011.

9. Afiyati, Y., dan Rachmawati, I.N. Methodologi penelitian kualitatif dalam riset keperawatan (edisi 1). Jakarta: Rajawali Pers; 2014.

10. Yeni Tasa, Ludji Ina Debora Ratu, Paun Rafael, Pemanfaatan voluntary counseling and testing oleh ibu rumah tangga terinfeksi HIV/AIDS. 2016, Diakses pada http://journal.unnes.ac.id/nju/index.php/kemas.

11. Anyta Nurul Diah, Komunikasi antarpribadikonselor terhadap odhadi klinik vctrsud kabupaten karanganyar. 2015. Diakses pada: http://eprints.ums.ac.id

12. Pratiwi Ayu, Wanufika Isna, dan Sukmara Yosep. health power support with drug compliance in HIV patients on class II Graduation a Tangerang. 2019, diakses pada : https://jurnal.stikesyatsi.ac.id

13. Pudijati, S. R. Kepatuhan (Adherence) terhadap Terapi Antiretroviral. 2016, diakses pada: http://www.depkes.go.id/article

14. Yulianti Aditiya Rina, Kualitas hidup orang dengan HIV dan AIDS (ODHA) di Kabupaten Jember. 2014, Diakses pada: https://repository.unej.ac.id 
15. Mardia , Ahmad Riris Andono, Riyanto Bambang Sigit, (2017). Kualitas hidup orang dengan HIV/AIDS berdasarkan kriteria diagnosis dan faktor lain di Surakarta. diakses pada: Berita Kedokteran Masyarakat (BKM Journal of Community Medicine and Public Health).

16. Sri, Nina, and Catur Septiawan. "Pengaruh Sikap, Dukungan Teman Sesama Wanita Pekerja Seks (WPS) dan Motivasi terhadap Perilaku
Pencegahan HIV/AIDS WPS." Jurnal Ilmiah Kebidanan Indonesia 9.02 (2019): 66-78.

17. Rini, Ageng Septa, and Ernita Prima Noviyani. "Konfirmasi Lima Faktor yang Berpengaruh terhadap Perilaku Remaja dalam Pencegahan HIV/AIDS." Jurnal Ilmiah Kebidanan Indonesia 9.04 (2019): 138-153. 